\title{
Implemenetasi Yuridis tentang Kedudukan \\ Memorandum of Understanding (mou) dalam Sistem Hukum Perjanjian Indonesia
}

\section{Fuad Luthfi}

Fakultas Syari'ah dan Ekonomi Islam UIN Antasari, Jl. Jendral Ahmad Yani Km

4,5 Banjarmasin

\begin{abstract}
This study will examine the Juridical Implemenetasi on the Status of Memorandum of Understanding (mou) in the Indonesian Legal System of the Memorandum of Understanding or abbreviated as $\mathrm{MoU}$ is the recording or documentation of the outcome of the initial negotiations in written form. The term Memorandum of Understanding should be distinguished in terms of theoretical and practical. Theoretically, the Memorandum of Understanding document is not legally binding, in order to be legally binding it must be followed up by making an agreement. Whereas when referring to the KUHPer which equates the Memorandum of Understanding with the agreement, although Article 1338 of the Criminal Code states that any legally binding treaty is binding as a law to the party making it (Pacta Sunt Servanda), but if the elements of the agreement Article 1320 of the Criminal Code is not fulfilled, then the Memorandum of Understanding is null and void, and has no legal force.
\end{abstract}

Keywords: Implemenetasi Juridis, Position Memorandum Of Understanding (Mou) Indonesian Treaty Law

Abstrak: Penelitian ini akan menelaah mengenai Implemenetasi Yuridis tentang Kedudukan Memorandum of Understanding (mou) dalam Sistem Hukum Perjanjian Indonesia Memorandum of Understanding atau disingkat MoU merupakan pencatatan atau pendokumentasian hasil negosiasi awal dalam bentuk tertulis. penggunaan istilah Memorandum of Understanding harus dibedakan dari segi teoritis dan praktis. Secara teoritis, dokumen Memorandum of Understanding tidak mengikat secara hukum, agar dapat mengikat secara hukum harus ditindaklanjuti dengan membuat suatu perjanjian. Sedangkan apabila mengacu pada KUHPer yang menyamakan Memorandum of Understanding dengan perjanjian, walaupun Pasal 1338 KUHPer mengatakan bahwa setiap perjanjian yang dibuat secara sah mengikat sebagai undang-undang bagi para pihak yang membuatnya (Pacta Sunt Servanda), akan tetapi apabila unsur-unsur sahnya perjanjian dalam Pasal 1320 KUHPer tidak terpenuhi, maka Memorandum of Understanding tersebut batal demi hukum, dan tidak mempunyai kekuatan hukum.

Kata Kunci: Implemenetasi Yuridis, Kedudukan Memorandum Of Understanding (Mou) Hukum Perjanjian Indonesia

\section{Pendahuluan}

Perjanjian telah menjadi bagian

yang penting didalam kehidupan manusia, termasuk dalam dunia bisnis.

Pelaku bisnis dalam melakukan kerja sama dituangkan dalam suatu perjanjian. Perjanjian dalam dunia bisnis lazimnya dilakukan secara tertulis, baik perjanjian yang dibuat secara notariil dihadapan Notaris, 
maupun perjanjian dibawah tangan yang dibuat oleh para pihak. Perjanjian di dalam Kitab Undang-Undang Hukum Perdata Indonesia diatur di dalam Buku III Tentang Perikatan, Pasal 1233 sampai dengan Pasal 1864. Kitab Undang-Undang Hukum Perdata Indonesia tidak mengenal dan tidak mengatur Memorandum of Understanding (MoU). MoU merupakan kesepakatan awal dalam kontrak yang dibuat berdasarkan sistem hukum Common Law. Kontrak yang dibuat memiliki sifat yang tidak berbeda dengan perjanjian, yaitu ikatan yang memiliki akibat hukum. Kontrak merupakan kesepakatan para pihak yang mempunyai akibat hukum yang mengikat bagi para pihak sebagai undang-undang sesuai dengan asas Pacta Sunt Servanda.

Hukum kontrak (hukum perjanjian) dalam hal ini memberikan sarana yang memungkinkan para pihak mengakomodasi seluruh kepentingannya. Kontrak merupakan janji yang mengikat dan janji-janji tersebut menimbulkan harapanharapan yang layak. Hukum kontrak dalam hal ini merupakan instrumen hukum yang berfungsi untuk menjamin pelaksanaan janji dan harapan itu. ${ }^{1}$ Sebelum transaksi bisnis berlangsung, biasanya terlebih dahulu dilakukan negosiasi awal. Negosiasi merupakan suatu proses upaya untuk mencapai kesepakatan dengan pihak lain.

1 Yohanes Sogar Simamora, Hukum Perjanjian (Prinsip Hukum KontrakPengadaan Barang dan Jasa oleh Pemerintah), LaksBangPressindo:Yogyakarta. 2009, h. 32-33
Negosiasi juga merupakan instrumen yang menjembatani pelbagai kepentingan pelaku bisnis dalam merumuskan hak dan kewajibannya. Dalam negosiasi inilah proses tawar menawar berlangsung.

Sebelum transaksi bisnis berlangsung, biasanya terlebih dahulu dilakukan negosiasi awal. Negosiasi merupakan suatu proses upaya untuk mencapai kesepakatan dengan pihak lain. Dalam negosiasi inilah proses tawar menawar berlangsung. Tahapan berikutnya pembuatan M.O.U merupakan pencatatan atau pendokumentasian hasil negosiasi awal tersebut dalam bentuk tertulis. M.O.U penting sebagai pegangan untuk digunakan lebih lanjut di dalam negosiasi lanjutan atau sebagai dasar untuk melakukan studi kelayakan. Maksudnya sebagai studi kelayakan adalah setelah pihak-pihak memperoleh M.O.U sebagai pegangan atau pedoman awal, baru dilanjutkan dengan tahapan studi kelayakan (feasibility study, due diligent) untuk melihat tingkat kelayakan dan prospek transaksi bisnis tersebut dari berbagai sudut pandang yang diperlukan misalnya ekonomi, keuangan, pemasaran, teknik, lingkungan, sosial budaya dan hukum. Hasil studi kelayakan ini diperlukan dalam menilai apakah perlu atau tidaknya melanjutkan transaksi atau negosiasi lanjutan. ${ }^{2}$

2 Munir Fuady, Hukum Kontrak, Dari Sudut Pandang Hukum Bisnis, Bandung: PT. Citra Aditya Bakti, 1999, h 3. 
Istilah Memorandum of Understanding (MoU) oleh para ahli disebut dengan 'Nota Kesepakatan', 'Nota Kesepahaman' atau 'Kontrak Awal'. Pada dasarnya suatu kontrak berawal dari suatu perbedaan atau ketidaksamaan kepentingan diantara para pihak. Sehingga perumusan hubungan kontraktual tersebut pada umumnya selalu diawali dengan proses negosiasi diantara para pihak. Setelah ada kesepahaman atau kesepakatan atas kehendak untuk mengadakan kontrak, maka para pihak biasanya akan membuat Memorandum of Understanding $(\mathrm{MoU})$ yang memuat keinginan masing-masing pihak sekaligus adanya tenggang waktu pencapaian kesepakatan untuk terjadinya kontrak. ${ }^{3}$

Pada dasarnya suatu perjanjian berawal dari suatu perbedaan kepentingan diantara para pihak. Sehingga perumusan hubungan kontraktual diawali dengan proses negosiasi diantara para pihak. Setelah ada kesepahaman atas kehendak untuk mengadakan kontrak tersebut, maka para pihak biasanya akan mengadakan suatu proses prakontraktual, salah satunya adalah pada saat proses nota kesepahaman atau sering juga disebut dengan istilah "Memorandum of Understanding”(MOU) dibuat.

Tahapan berikutnya adalah
pembuatan memorandum of
understanding (MOU). ${ }^{4}$ Memorandum of

3 Huala Adolf, Dasar-dasar Hukum Kontrak Internasional, edisi Revisi, Bandung: Refika Aditama, 2008, h. 29.

4 Agus Yudha Hernoko, Hukum Perjanjian, Asas Proporsionalitas dalamKontrak
Understanding (MoU) sebenarnya tidak dikenal dalam hukum konvensional di Indonesia, terutama dalam hukum kontrak di Indonesia. Di dalam peraturan perundang-undangan Indonesia, tidak ada ketentuan yang secara khusus mengatur tentang Memorandum of Understanding (MoU). ${ }^{5}$

Adapun dasar berlakunya Memorandum of Understanding $(\mathrm{MoU}) \mathrm{di}$ Indonesia adalah

didasarkan pada asas kebebasan berkontrak, sebagaimana diatur dalam Pasal 1338 KUHPerdata, yang berbunyi: ${ }^{6}$

(1) "Semua persetujuan yang dibuat sesuai dengan undang-undang, berlaku sebagai undang-undang bagi mereka yang membuatnya.

(2) Persetujuan itu tidak dapat ditarik kembali selain dengan kesepakatan kedua belah pihak, atau karena alasan-alasan yang ditentukan oleh undangundang.Persetujuan harus dilaksanakan dengan itikad baik".

Kebebasan berkontrak artinya seseorang bebas untuk mengadakan perjanjian, bebas mengenai apa yang diperjanjikan, bebas pula menentukan

Komersial, Yogyakarta: LaksBang Mediatama, 2008. h 100

${ }^{5}$ Fajar Sandy Wijaya, dkk, Kajian Yuridis Kekuatan Hukum Memorandum of Understanding (MoU) Indonesia- Singapura Tentang Kerjasama Kawasan Ekonomi Khusus, Jember: Universitas Jember, 2013, h. 2.

${ }^{6}$ Niniek Suparni, Kitab Undang-Undang Hukum Perdata (KUHPerdata), Jakarta: Rineka Cipta, 2013, h. 334. 
bentuk kontraknya. ${ }^{7}$ Asas kebebasan berkontrak memberikan kebebasan bagi pihak-pihak yang berkontrak, namun asas kebebasan berkontrak itu juga tidak memberikan kebebasan yang mutlak. Kitab Undang-Undang Hukum Perdata sendiri memberikan beberapa pembatasan terhadap asas kebebasan berkontrak ini, antara lain dibatasi oleh undang-undang, kesusilaan dan ketertiban umum.

Berdasarkan asas kebebasan berkontrak, maka para pihak diberi kebebasan untuk menentukan materi muatan atau substansi Memorandum of Understanding akan mengatur apa saja, sepanjang tidak bertentangan dengan undang-undang, kesusilaan, dan ketertiban umum, serta sepanjang penyusunan Memorandum of Understanding itu memenuhi syaratsyarat sahnya sebuah perjanjian sebagaimana tertuang dalam Pasal 1320 Kitab Undang- Undang Hukum Perdata.

Memorandum of understanding sebenarnya tidak dikenal dalam hukum konvensional di Indonesia, terutama dalam hukum kontrak di Indonesia. Di dalam peraturan perundang-undangan Indonesia, tidak ada ketentuan yang secara khusus mengatur mengenai memorandum of understanding. KUHPer tidak mengenal dan tidak mengatur Memorandum of Understanding (MoU). $\mathrm{MoU}$ merupakan kesepakatan awal dalam kontrak yang dibuat berdasarkan

7 Abdul R.Salimin, Hukum Bisnis Untuk Perusahaan (Teori Dan Contoh Kasus), Jakarta: Kencana, 2010, h. 46 sistem hukum Common Law. Kontrak yang dibuat memiliki sifat yang tidak berbeda dengan perjanjian, yaitu ikatan yang memiliki akibat hukum. Kontrak merupakan kesepakatan para pihak yang mempunyai akibat hukum yang mengikat bagi para pihak sebagai undang-undang sesuai dengan asas Pacta Sunt Servanda.

Adapun dasar berlakunya memorandum of understanding di Indonesia adalah didasarkan pada asas kebebasan berkontrak. Selain asas kebebasan berkontrak, salah satu asas yang menjadi dasar berlakunya memorandum of understanding di Indonesia adalah asas kebiasaan. Yang dimaksud dengan asas kebiasaan bahwa suatu perjanjian tidak hanya mengikat untuk apa yang secara tegas diatur, akan tetapi juga hal-hal yang menurut kebiasaan lazim diikuti. Tidak diaturnya Memorandum of Understanding di dalam hukum konvesional kita, maka banyak menimbulkan kesimpangsiuran dalam prakteknya, mengingat Memorandum of Understanding hanya merupakan suatu nota-nota kesepakatan saja.

Selain asas kebebasan berkontrak, salah satu asas yang menjadi dasar berlakunya Memorandum of Understanding (MoU) adalah asas kebiasaan. Asas kebiasaan maksudnya adalah suatu perjanjian tidak hanya mengikat untuk apa yang secara tegas diatur, akan tetapi juga hal-hal yang menurut kebiasaan lazim diikuti. Tidak diaturnya Memorandum of Understanding $(\mathrm{MoU})$ ini dalam hukum kita, maka 
dalam prakteknya banyak menimbulkan kesimpangsiuran.

\section{Konsep Tentang Hukum Perjanjian di Indonesia}

\section{Pengertian Perjanjian}

Rumusan mengenai pengertian perjanjian atau persetujuan ini terdapat di dalam Kitab Undang-Undang Hukum Perdata pada Buku III Pasal 1313, yaitu :

"perjanjian adalah suatu perbuatan dengan mana satu orang atau lebih mengikatkan dirinya terbadap satu orang lain atau lebih".

Selain perumusan tentang pengertian perjanjian yang terdapat dalam KUH Perdata tersebut, beberapa Sarjana Hukum yang memberikan pengertian terhadap isitilah perjanjian ini, yaitu sebagai berikut :

\section{a. Menurut Prof. R. Subekti}

"Suatu perjanjian adalab suatu peristiwa dimana seorang berjanji kepada seorang lain atau dimana dua orang itu saling berjanji untuk melaksanakan suatu hal". ${ }^{8}$

\section{b. Menurut}

Wirjono

\section{Prodjodikoro}

"Perjanjian adalah suatu perbubungan bukum mengenai harta benda kekayaan antara dua pibak, dalam mana satu pibak berjanji atau dianggap untuk. melakukan sesuatu hal, sedang pihak lain berhak menuntut pelaksanaan janji itu". ?

\section{c. Menurut Hofmann}

"Perikatan adalab suatu bubungan bukum antara sejumlah terbatas subjek-

${ }^{8}$ R. Subekti, Op. cit, h. 1.

9 Wirjono Prodjodikoro, 1981, Hukum Perdata Tentang Persetujuan-persetujuan Tertentu, Bandung: Sumur, h. 11. subek bukum sebubungan dengan itu seorang atau beberapa orang dari padanya mengikatkan dirinya untuk bersikap menurut cara-cara tertentu terhadap pihak yang lain, yang berhak atas sikap yang demikian itu". 10

\section{d. Menurut R. Syahrani}

"Perikatan adalab bubungan bukum antara dua pibak di dalam lapangan harta kekayaan, dimana pihak yang satu (kreditur) berbak atas prestasi dan pibak yang lain (debitur) berkewajiban memenubi prestasi itu". 11

Dari pengertian-pengertian tersebut dapat ditarik suatu kesimpulan, bahwa dalam suatu perikatan paling sedikit terdapat satu hak dan satu kewajiban. Suatu persetujuan dapat menimbulkan satu atau beberapa perikatan, tergantung dari jenis persetujuannya.

2. Syarat-syarat Sahnya Perjanjian

Tentang syarat-syarat yang diperlukan untuk sahnya suatu perjanjian, dengan jelas telah diatur dalam Pasal 1320 KUH Perdata, yaitu :
a. Sepakat mereka yang mengikatkan dirinya
b. Kecakapan untuk membuat suatu perjanjian
c. Suatu hal tertentu
d. Suatu sebab yang halal

\section{1) Sepakat mereka yang mengikatkan dirinya}

10 R. Setiawan, 1987, Pokok-Pokok Hukum Perikatan, (Bandung: Binacipta), hal. 2.

${ }^{11}$ H. Riduan syahrani, 2006, Seluk Beluk dan Asas-Asas Hukum Perdata, (Bandung: Alumni), hal. 203. 
Para pihak dalam perjanjian yaitu, manusia atau badan hukum telah menyatakan kesepakatan atau persetujuan yang mana akhirnya akan terbentuk suatu pertemuan kehendak, para pihak yang membuat perjanjian telah sepakat atau ada persesuaian kemauan atau saling menyetujui kehendak masing-masing, yang dilahirkan oleh para pihak dengan tidak ada paksaan, kekeliruan dan penipuan, persetujuan mana yang dapat dinyatakan secara tegas maupun secara diam-diam. ${ }^{12}$

Dalam hukum perjanjian adanya suatu azas yang dinamakan azas konsensualitas yang terdapat dalam Pasal 1320 KUH Perdata. Istilah ini berasal dari bahasa latin yaitu Consensus yang berarti sepakat, maksud dari kata sepakat disini adalah bahwa pada azasnya perjanjian atau perikatan yang timbul karenanya, itu sudah dilahirkan sejak detik tercapainya kesepakatan. Azas konsensualitas bukanlah berarti untuk suatu perjanjian disyaratkan adanya kesepakatan karena hal ini sudah semestinya, suatu perjanjian juga dinamakan persetujuan, berarti kedua belah pihak sudah setuju atau sepakat mengenai suatu hal. ${ }^{13}$

Untuk menentukan telah terjadinya kata "sepakat" ada beberapa teori yang dikemukakan oleh para sarjana, yaitu : ${ }^{14}$

a) Uitings theorie (teori saat melahirkan kemauan). Menurut

\footnotetext{
12 Ibid, h. 214

13 R. Subekti, Op. cit., h. 15.

14 R. Syahrani, Op. cit., h. 215.
}

teori ini perjanjian terjadi apabila atas penawaran telah dilahirkan kemauan menerimanya dari puhak lain. Kemauan ini dapat dikatakan telah dilahirkan pada waktu pihak lain mulai menulis surat penermaan.

b) Verzend theorie (teori saat mengirim surat penerimaan). Menurut teori ini perjanjian terjadi pada saat surat penerimaan dikirimkan kepada si penawar.

c) Onvangs theorie (teori saat menerima surat penerimaan). Menurut teori ini perjanjian pada saat menerima surat penerimaan/sampai di alamat penawar.

d) Vernemings theorie (teori saat mengetahui surat penerimaan). Menurut teori ini perjanjian baru terjadi, apabila si penawar telah membuka dan membaca surat penerimaan itu.

Sebagian besar dari perjanjianperjanjian ini selalu bersumber pada kata sepakat, yaitu suatu "persetujuan" antara kedua belah pihak. Dari peristiwa tersebut akan menimbulkan suatu peristiwa hubungan hukum diantara kedua belah pihak yang mengadakan perjanjian tersebut dan kedua belah pihak telah terikat oleh isi perjanjian yang dibuatnya. Adapun bentuk dari perjanjian itu bisa tertulis dan secara lisan yang berisi suatu rangkaian perkataan yang mengandung janji-janji atau kesanggupan. 


\section{2) Adanya kecakapan untuk membuat suatu perjanjian}

Adapun yang dimaksud dengan kecakapan disini adalah bahwa subjek dalam suatu perjanjian harus sudah dianggap cakap untuk melakukan perbuatan sandiri menurut ketentuan hukum. Cakap merupakan syarat umum untuk melakukan perbuatan hukum secara sah, yaitu harus sudah dewasa, sehat akal fikiran dan tidak dilarang oleh suatu peraturan perundang-undangan untuk melakukan sesuatu perbuatan tertentu. ${ }^{15}$

Selanjutnya dalam Pasal 1330 KUH Perdata, ada beberapa golongan orang yang dinyatakan tidak cakap untuk melakukan sendiri perbuatanperbuatan hukum, yaitu :

a) Orang-orang yang belum dewasa. Belum dewasa adalah mereka yang belum mencapai umur genap dua puluh satu tahun dan sebelumnya belum kawin.

b) Mereka yang ditaruh di bawah pengampuan. Orang-orang yang diletakkan di bawah pengampuan adalah setiap orang dewasa yang selalu berada dalam keadaan dungu, sakit otak atau mata gelap dan boros.

c) Orang-orang perempuan. Dalam hal-hal yang ditetapkan oleh undang-undang, dan pada umumnya semua orang kepada siapa undang-undang telah melarang membuat perjanjianperjanjian tertentu.

\footnotetext{
${ }^{15} \mathrm{Ibid}$, h. 217
}

Jadi dengan demikian yang dimaksud dengan adanya kecakapan untuk membuat suatu perikatan, yaitu bahwa para pihak di dalam perjanjian tersebut diharuskan :

(1) Mampu untuk melakukan perbuatan hukum

(2) Mampu melakukan perjanjian yang hendak dibuatnya

Dengan demikian, syarat kecakapan untuk membuat suatu perjanjian ini mengandung kesadaran untuk melindungi baik bagi dirinya, bagi miliknya maupun dalam hubungannya dengan keselamatan keluarganya. ${ }^{16}$

\section{3) Adanya Suatu Hal Tertentu}

Suatu hal tertentu dalam perjanjian adalah barang yang menjadi objek suatu perjanjian. Menurut Pasal 1333 KUH Perdata barang yang menjadi objek suatu perjanjian ini harus tertentu, setidak-tidaknya harus ditentukan jenisnya, sedangkan jumlahnya tidak perlu ditentukan asalkan saja kemudian dapat ditentukan atau diperhitungkan.

Kemudian dalam Pasal 1332 KUH Perdata ditentukan bahwa barang-barang yang dapat dijadikan objek perjanjian hanyalah barangbarang yang dapat diperdagangkan. Lazimnya barang-barang yang dapat dipergunakan untuk kepentingan umum dianggap sebagai barang barang di luar perdagangan, sehingga tak bisa dijadikan objek perjanjian (selanjutnya lihat Pasal 521, 522, $523 \mathrm{KUH}$ Perdata). 
Jurnal Syariah: Jurnal Ilmu Hukum dan Pemikiran

Vol 17, Nomor 2 Desember 2017

Hal-hal tersebut sangat perlu diperhatikan oleh para pihak yang membuat perjanjian, karena untuk dapat menentukan atau menetapkan kewajiban si berhutang (debitur) apabila terjadi suatu perselisihan. Yang menjadi objek daripada suatu perjanjian tidak selalu harus sudah ada pada saat perjanjian, akan tetapi bisa juga belum ada.

\section{4) Adanya Suatu Sebab Yang Halal}

Suatu sebab yang halal merupakan syarat yang terakhir untuk sahnya suatu perjanjian. Mengenai syarat ini Pasal 1335 KUH Perdata menyatakan bahwa suatu perjanjian tanpa sebab, atau yang telah dibuat karena sesuatu sebab yang palsu atau terlarang, tidak mempunyai kekuatan. Jadi yang dimaksud dengan sebab dari suatu perjanjian adalah isi dari perjanjian itu sendiri. Akhirnya Pasal 1337 KUH Perdata menentukan bahwa suatu sebab dalam perjanjian tidak boleh bertentangan dengan undangundang, kesusilaan dan ketertiban umum. ${ }^{17}$

Lebih lanjut R. Subekti, menggolongkan 4 (keempat) syarat untuk sahnya suatu perjanjian ke dalam 2 (dua) golongan, yaitu : ${ }^{18}$

a. Syarat subjektif, yaitu untuk dua syarat yang pertama, krena kedua syarat itu mengenai subjek daripada perjanjian.

b. Syarat objektif, yaitu untuk dua syarat yang terahkir, kerena

${ }^{17}$ Ibid, h . 221

18 R. Subekti, Op. cit., h. 17 kedua syarat itu mengenai objek daripada perjanjian.

Untuk sahnya suatu perjanjian syaratsyarat tersebut di atas harus dipenuhi, apabila syarat subjektif tidak dipenuhi, maka perjanjian dapat dibatalkan oleh hakim atas permintaan pihak yang tidak cakap atau yang memberikan kesepakatan secara tidak bebas. Sedangkan kalau syarat objektif tidak dipenuhi, maka perjanjian batal demi hukum, artinya dari semula tidak pernah dilahirkan suatu perjanjian dan tidakpernah ada perikatan. Sehingga tiada dasar untuk saling menuntut di muka hakim (pengadilan).

\section{Unsur-Unsur Perjanjian}

Adapun unsur-unsur / bagianbagian perjanjian adalah : ${ }^{19}$

a. Unsur Essentialia. Yaitu bagian-bagian daripada perjanjian yang tanpa itu perjanjian tidak akan mungkin ada, maksudnya unsur pokok yang harus ada dalam perjanjian. Misalnya harga adalah essentialia atau inti bagi perjanjian jual beli, identitas para pihak serta kesepakatan.

b. Unsur Naturalia. Yaitu bagian-bagian yang oleh undang-undang ditentukan sebagai peraturan-peratutan yang bersifat mengatur, maksudnya unsure yang telah ada dalam perjanjian walaupun tidak dituangkan

\footnotetext{
${ }^{19}$ R. Setiawan, Op. cit, h. 50.
} 
secara tegas dalam perjanjian tersebut. Misalnya adanya itikad baik, serta jaminan tidak ada cacad tersembunyi dalam suatu barang.

c. Unsur Accidentalia. Yaitu bagian-bagain yang oleh para pihak ditambahkan dalam perjanjian, dimana undangundang tidak mengaturnya, misalnya jual beli rumah beserta alat-alat rumah tangganya.

\section{Macam-Macam Perjanjian}

Adapun macam-macam perjanjian yang dikenal dalam ilmu pengetahuan hukum adalah $:^{20}$

a. Perjanjian Obligatoir yaitu : suatu perjanjian yang hanya membebankan kewajiban kepada para pihak, sehingga dengan perjanjian ini baru menimbulkan perikatan. Misalnya pada perjanjian jual beli, maka dengan sahnya perjanjian jual beli belum menyebabkan beralihnya benda atau barang yang dijual itu tetapi baru akan menimbulkan perikatan yaitu bahwa pihak pembeli diwajibkan membayar harganya untuk beralihnya barang tersebut secara nyata harus ada penyerahan baik yuridis maupun nyata. Yang termasuk perjanjian obligatoir, yaitu :

${ }^{20}$ Ibid, h. 52
1) Perjanjian sepihak dan timbal balik. Perjanjian timbal balik adalah perjanjian yang menimbulkan kewajiban pokok kepada kedua belah pihak. Misalnya jual beli, sewa menyewa. Perjanjian sepihak adalah perjanjian dimana hanya terdapat kewajiban pada salah satu pihak saja. Misalnya hibah.

2) Perjanjian cuma-cuma dan atas beban. Perjanjian cuma-cuma adalah perjanjian dimana salah satu pihak mendapatkan

keuntungan dari pihak yang lain secara cumacuma. Perjanjian atas beban adalah perjanjian dimana terhadap prestasi pihak yang satu terdapat prestasi pihak yang lain dan keduanya saling berhubungan. Misalnya jual beli, sewa menyewa.

3) Perjanjian Konsensual, Riil, dan Formil. Perjanjian konsensual adalah perjanjian yang terjadi dengan kata sepakat. Perjanjian riil adalah perjanjian selain diharuskan adanya kata sepakat juga diikuti 


$\begin{array}{lrl}\text { dengan penyerahan } & \text { menimbulkan, } \\ \text { barang, misalnya } & \text { mengubah atau } \\ \text { penitipan barang. } & \text { menghapuskan hak-hak } \\ \text { Perjanjian formil adalah } & \text { kebendaan. } \\ \text { perjanjian yang harus } & \text { 3) } & \begin{array}{l}\text { Perjanjian pembuktian. } \\ \text { diadakan dengan bentuk }\end{array} \\ \text { Adalah para pihak bebas } \\ \text { tertentu , seperti harus } & \text { untuk mengadakan } \\ \text { dibuat dengan akta } & \text { perjanjian mengenai } \\ \text { notaris, misalnya } & \text { alat-alat pembuktian } \\ \text { pendirian PT. } & \text { yang akan mereka } \\ \text { Perjanjian bernama dan } & \text { gunakan dalam suatu } \\ \text { tidak bernama. } & \text { proses. }\end{array}$

Perjanjian bernama adalah perjanjian yang pengaturannya telah diatur dalam Buku III

\section{Berakhirnya Perjanjian}

Hapusnya suatu persetujuan harus benar-benar dibedakan daripada $\mathrm{KUH}$ Perdata.

Perjanjian tidak bernama adalah perjanjian yang tidak disebutkan dan tidak diatur dalam dalam KUH Perdata, dimana terdapatnya asas kebebasan berkontrak.

b. Perjanjian-perjanjian lainnya, yaitu :

1) Perjanjian Leberatoir. Adalah perbuatan hukum yang atas dasar sepakat para pihak menghapuskan perikatan yang telah ada.

2) Perjanjian kebendaan. Adalah perjanjian yang diatur dalam Buku II KUH Perdata yang merupakan perjanjian untuk menyerahkan benda

atau hapusnya suatu perikatan, karena suatu perikatan dapat hapus, sedangkan persetujuannya yang merupakan sumbernya masih tetap ada. Misalnya pada persetujuan jual beli, dengan dibayarnya harga maka perikatan mengenai pembayaran menjadi hapus, sedangkan persetujuannya belum, karena perikatan mengenai penyerahan barang belum terlaksana. Hanya jika semua perikatan-perikatan daripada persetujuan telah hapus seluruhnya, maka persetujuannyapun akan berakhir. Dalam hal ini, hapusnya persetujuan sebagai akibat daripada hapusnya perikatan-perikatannya. ${ }^{21}$

Sebaliknya hapusnya suatu persetujuan dapat pula mengakibatkan hapusnya perikatan-perikatannya, yaitu apabila suatu persetujuan hapus dengan berlaku surut, misalnya sebagai akibat daripada pembatalan berdasarkan wanprestasi yaitu Pasal 1266 KUH ${ }^{21}$ R. Setiawan, Op. cit., h. 68. 
Perdata, maka semua perikatan yang telah terjadi menjadi hapus, perikatanperikatan tersebut tidak perlu lagi dipenuhi dan apa yang telah dipenuhi harus pula ditiadakan. Akan tetapi, dapat juga terjadi bahwa persetujuan berakhir atau hapus untuk waktu selanjutnya, jadi kewajiban-kewajiban yang telah ada tetap ada. Dengan pernyataan mengakhiri persetujuan, persetujuan sewa menyewa dapat diakhiri, akan tetapi perikatan untuk membayar uang sewa atas sewa yang dinikmati tidak menjadi hapus karenanya. ${ }^{22}$

Jadi suatu persetujuan dapat hapus atau berakhir, karena $:^{23}$

a. Ditentukan dalam persetujuan oleh para pihak, misalnya persetujuan akan berlaku untuk waktu tertentu.

b. Undang-undang menentukan batas berlakunya suatu persetujuan.

c. Para pihak atau Undangundang dapat menentukan bahwa dengan terjadinya peristiwa tertentu, maka persetujuan akan hapus. Misalnya salah satu pihak meninggal, maka persetujuan menjadi hapus:

1) persetujuan kerja (Pasal 1603 j JUH Perdata).

2) persetujuan pemberian kuasa (Pasal 1813 KUH Perdata)

\footnotetext{
22 Ibid

${ }^{23} \mathrm{Ibid}$, h. 69.
}

d. Suatu pernyataan penghentian perjanjian atau opregging. Pernyataan ini dapat dilakukan oleh kedua belah pihak ataupun oleh salah satu pihak. Pernyataan ini hanya ada dalam perjanjian-perjanjian yang bersifat sementara, misalnya perjanjian kerja.

e. Perjanjian atau persetujuan hapus karena adanya keputusan hakim.

f. Apabila tujuan perjanjian telah tercapai, yaitu semua kembali pada keadaan semula seolaholah tidak pernah ada suatu perjanjian.

Hal-hal yang mengakibatkan hapusnya perikatan dalam $\mathrm{KUH}$ Perdata disebutkan dalam Pasal 1381, adalah :

1) Karena pembayaran

2) Karena penawaran pembayaran tunai, diikuti dengan penyimpanan atau penitipan

3) Karena pembaharuan utang

4) Karena perjumpaan utang atau kompensasi

5) Karena percampuran utang

6) Karena pembebasan utang

7) Karena musnahnya barang yang terutang

8) Karena kebatalan dan pembatalan

9) Karena berlakunya syarat batal

10) Karena lewat waktu (daluwarsa).

Konsep Tentang Memorandum of Understanding (MoU) 


\section{Pengertian Memorandum of Understanding(MoU)}

Istilah MoU berasal dari dua kata, yaitu Memorandum dan Understanding. Secara gramatikal MoU diartikan sebagai nota kesepahaman. Munir Fuady, mengartikan MoU sebagai berikut:

"Perjanjian pendahuluan, dalam arti nantinya akan diikuti dan dijabarkqn dalam perjanjian lain yang mengaturnya secara detail, karena itu, memorandum of understanding berisikan hal-halyang pokok saja. Adapun mengenai lain-lain aspek dari memorandum of understanding relatif sama dengan perjanjian perjanjian lain "24

Erman Rajagukguk mengartikan MoU sebagai berikut:

'Dokumen yang memuat saling pengertian di antara para pihak sebelum perjanjian dibuat. Isi dari Memorandum of Understanding harus dimasukkan ke dalam kontrak, sehingga ia mempunyai kekuatan mengikat". 25

Unsur-unsuryang terkandung dalam MoU ada tiga, ketiga unsur yang dimaksud, yaitu:

a. MoU sebagai perjanjian pendahuluan, yang merupakan perjanjian awal yang dilakukan oleh para pihak;

b. Isi MoU adalah mengenai halhalyang pokok;

24 Salim HS dkk, Perancangan Kontrak \& Memorandum of Understanding (MoU), Jakarta: Sinar Grafika, 2007, h. 91

${ }^{25} \mathrm{Ibid}$ c. Isi MoU dimasukkan dalam kontrak. ${ }^{26}$

Para pihak yang membuat $\mathrm{MoU}$ tersebut adalah subjek hukum, baik berupa badan hukum publik maupun badan hukum privat. Badan hukum publik, misalnya negara, pemerintah provinsi/kabupaten/kota. Adapun badan hukum privat, antara lain Perseroan Terbatas (P'T), Koperasi, dan Yayasan. Wilayah keberlakuan dari MoU itu, bisa regional, nasional, maupun internasional. Substansi $\mathrm{MoU}$ adalah kerja sama dalam berbagai aspek kehidupan dan jangka waktunya tertentu.

Para pihak yang terikat dalam MoU tidak hanya badan hukum privat, tetapi juga antara negara yang satu dengan negara yang lainnya. Pada hakikatnya substansi dari MoUmisalnya berisi suatu perjanjian kerja sama dalam berbagai bidang kehidupan, dibidang ekonomi, pendidikan, kesehatan, pertahanan keamanan (hankam), keuangan, keahlian, dan lain-lain. Dalam setiap MoU juga dicantumkan tentang jangka waktunya. Jangka waktu berlakunya MoU adalah berkaitan dengan lamanya kerja sama itu dilakukan, misalnya jangka waktu tiga bulan, enam bulan, setahun, dan sebagainya.

MoU dalam pengertian idealnya sebenarnya merupakan suatu bentuk perjanjian atau kesepakatan awal menyatakan langkah pencapaian saling pengertian antara kedua belah pihak untuk melangkah kemudian pada 
penandatanganan suatu kontrak. ${ }^{27}$ Bisa dikatakanMoUsebagai kesepakatan prakontrak, yaitu kesepakatan dimana para pihak melakukan penjajakan untuk saling mengenal dalam membangun kesamaan pengertian sebelum masuk kedalam ikatan hukum secara lebih formal melalui kontrak. Selain itu, MoU juga terkadang dibuat sebagai wadah untuk bernegosiasi, sebelum masuk ke kontrak sesungguhnya, negosiasi disini maksudnya adalah jika ada para pihak atau salah satu pihak yang tidak puas dengan praktik perjanjian MoUnya maka pihak yang tidak puas itu dapat bernegosiasi ulang terhadap $\mathrm{MoU}$ dengan pihak yang bersangkutan yang ada dalam MoU itu sendiri.

Berdasarkan penjelasan diatas,
dapat dinyatakan bahwa MoU bukanlah merupakan kontrak karena memang masih merupakan kegiatan prakontrak, sehingga di dalamnya sengaja tidak dimasukkan "intention to create legal relation" 28 oleh para pihak, dalam prakteknya terkadang para pihak dengan berbagai pertimbangan sengaja memasukan ketentuan konsekwensi hukum dalam sebuah MoU.

Ada 3 pertimbangan para pihak memasukan konsekwensi hukum dalam MoU tersebut, ketiga pertimbangan para pihak memasukan

${ }^{27}$ Ricardo Simanjuntak, 2011, Hukum Kontrak, Teknik Perancangan Kontrak Bisnis, Jakarta: Kontan Publishing, 2011, h. 45.

28 intention to create legal relationadalah niat untuk menciptakan hubungan hukum, maksud hubungan hukum disini adalah hubungan hak dan kewajiban yang saling mengikat antar para pihak konsekwensi hukum tersebut antara lain adalah :

1) Untuk menghindari tidak adanya niat baik atau ketidakseriusan salah satu pihakyang membuat MoU dalam pelaksanaan perjanjian prakontrak seperti misalnya secara sewenang wenangmembatalkan sendiri rencana tanpa alasan yang kuat;

2) Untuk menghindari kerugian baik finansial maupun non finansial yang telah dikeluarkan para pihak selama kegiatan prakontrak;

3) Menjaga kerahasiaan dari data/informasi yang diberikan selama kegiatan prakontrak. Apabila sebuah MoU sudah mengandung unsur konsekwensi hukum seperti ini, maka walaupun berbentuk MoU namun perjanjian tersebut sudah merupakan sebuah kontrak.

\section{Dasar Hukum Memorandum of Understanding(MoU)}

Ketentuan khusus mengenaiMoU tidak ditemukan dalam berbagai ketentuan perundangundangan, namun apabila kita memperhatikan substansi MoU, maka jelaslah bahwa di dalamnya berisi kesepakatan para pihak tentang hal-hal yang bersifat umum20. Ketentuan yang mengatur tentang kesepakatan telah dituangkan dalam Pasal 1320 KUHPerdata. Pasal 1320 KUHPerdata 
Jurnal Syariab: Jurnal Imu Hukum dan Pemikiran

Vol 17, Nomor 2 Desember 2017
Implementasi Yuridis .. 179-202

Fuad Luthfi ini isinya adalah tentang aturan yang mengatur mengenai syaratsyaratsahnya suatu perjanjian.

Salah satu syarat sahnya perjanjian itu adalah adanya konsensus para pihak, di samping itu yang dapat di jadikan dasar hukum pembuatan MoU adalah Pasal 1338 KUHPerdata. Pasal 1338 KUH Perdata berbunyi:

"Semua perjanjian yang dibuat secara sah berlaku sebagai undangundang bagi mereka yang membuatnya".

Asas kebebasan berkontrak, adalah suatu asas yang memberikan kebebasan kepada para pihak untuk:

a. membuat atau tidak membuat perjanjian;

b. mengadakan perjanjian dengan siapa pun;

c. menentukan isi perjanjian, pelaksanaan, dan persyaratannya; dan

d. menentukan bentuknya perjanjian, yaitu tertulis atau lisan.

Asas ini merupakan asas yang sangat penting dalam pembuatan $\mathrm{MoU}$, karena asas ini memperkenankan para pihak, apakah itu, antara badan hukum ataupun individu dengan badan hukum atau individu dengan individu untuk melakukan atau membuat $\mathrm{MoU}$ yang sesuai dengan kebutuhan maupun keinginan para pihak dalam MoUasalkan isinya tidak melanggar peraturanperundang-undang yang berlaku.

\section{Jenis-Jenis Memorandum of Understanding(MoU)}

$\mathrm{MoU}$ dapat dibagi menurut negara dan kehendak para pihak. MoU menurut negara merupakan $\mathrm{MoU}$ yang dibuat antara negara yang satu dengan negara yang lainnya. MoU menurut negara yang membuatnya dapat dibagi menjadi dua jenis, yaitu:

a. MoU yang bersifat nasional; dan

b. MoUyang bersifat internasional. ${ }^{29}$

MoUyang bersifat nasional merupakan MoU yang kedua belah pihaknya adalah warga negara atau badan hukum Indonesia, misalnyaMoU yang dibuat antara badan hukum Indonesia dengan badan hukum Indonesia lainnya atau antara PT dengan pemerintah daerah. MoU yang bersifat internasional merupakan nota kesepahaman yang dibuat antara pemerintah Indonesia dengan pemerintah negara asing dan/atau antara badan hukum Indonesia dengan badan hukum negara asing.MoU menurut kehendak para pihak yang membuatnya merupakan MoU yang dibuat oleh para pihak yang sejak awal telah menyetujui kekuatan mengikat dari MoU tersebut.

\section{Tujuan}

Dibuatnya

Memorandum

of Understanding (MoU)

MoUpada prinsipnya dibuat oleh para pihak, tentunya mempunyai tujuan tertentu. Munir Fuady telah

\footnotetext{
${ }^{29}$ Ricardo Simanjuntak, Op. cit, h.. 50
} 
Jurnal Syariab: Jurnal Imu Hukum dan Pemikiran

Vol 17, Nomor 2 Desember 2017

mengemukakan tujuan dibuatnya MoU. Tujuan MoU adalah:

a. Untuk menghindari kesulitan pembatalan suatu agreement nantinya, dalam hal prospek bisnisnya belum jelas benar, belum jelas benar disini dapat diartikan belum bisa dipastikan apakah kesepakatan kerja sama tersebut akan ditindaklanjuti, sehingga dibuatlah $\mathrm{MoU}$ yang pembatalannya lebih mudah dari pada perjanjian;

b. Penandatanganan kontrak masih lama karena masih dilakukan negosiasi yang alot, karena itu daripada tidak ada ikatan apa-apa sebelum ditandatangani kontrak tersebut, dibuatlah MoU yang akan berlak sementara waktu;

c. Adanya keraguan para pihak dan masih perlu waktu untuk pikir-pikir dalam hal penandatanganan suatu kontrak, sehingga untuk sementara dibuatlah MoU

d. MoU dibuat dan ditandatangani oleh pihak eksekutif teras dari suatu perusahaan, sehingga untuk suatu perjanjian yang lebih rinci harus dan semestinya dirancang dan dinegosiasi khusus oleh staf - stafyang lebih rendah tetapi lebih menguasai secara teknis contohnya jika mengenai $\mathrm{MoU}$ ini adalahlegal officer. ${ }^{30}$

\section{Kedudukan Hukum Memorandum of Understanding (MoU)}

Di dalam berbagai peraturan perundang-undangan tidak ditemukan ketentuan yang khusus mengatur tentang Memorandum of Understanding, namun apabila kita memperhatikan substansi Memorandum of Understanding, maka jelaslah bahwa di dalamnya berisi kesepakatan para pihak tentang hal-hal yang bersifat umum. Memorandum of Understanding atau disingkat $\mathrm{MoU}$ sebagaimana telah diuraikan merupakan pencatatan atau pendokumentasian hasil negosiasi awal dalam bentuk tertulis.

Menurut Hikmahanto Juwana, penggunaan istilah Memorandum of Understanding harus dibedakan dari segi teoritis dan praktis. Secara teoritis, dokumen Memorandum of Understanding tidak mengikat secara hukum, agar dapat mengikat secara hukum harus ditindaklanjuti dengan membuat suatu perjanjian. Sedangkan apabila mengacu pada KUHPer yang menyamakan Memorandum of Understanding dengan perjanjian, walaupun Pasal 1338 KUHPer mengatakan bahwa setiap perjanjian yang dibuat secara sah mengikat sebagai undang-undang bagi para pihak yang membuatnya (Pacta Sunt Servanda), akan tetapi apabila unsur-unsur sahnya

30 Munir Fuady, Hukum Bisnis dalam Teori dan Praktik, Bandung: Citra Aditya Bhakti, 1997, h.91. 
perjanjian dalam Pasal 1320 KUHPer tidak terpenuhi, maka Memorandum of Understanding tersebut batal demi hukum, dan tidak mempunyai kekuatan hukum. ${ }^{31}$

Menurut Erman Rajagukguk, memorandum of understanding adalah dokumen yang memuat saling pengertian diantara para pihak sebelum perjanjian dibuat. Isi dari memorandum of understanding harus dimasukan ke dalam perjanjian, sehingga ia mempunyai kekuatan mengikat. ${ }^{32}$ Berdasarkan definisi tersebut, dapat dilihat bahwa memorandum of understanding tidak mengatur hubungan hukum antara para pihak. Dalam KUH Perdata maupun dalam peraturan perundang-undangan lainnya tidak ditemukan ketentuan khusus yang mengatur tentang memorandum of understanding, sehingga tidak memberikan kepastian hukum kepada para pihak yang membuat memorandum of understanding tersebut.

Memorandum of understanding penting sebagai pegangan untuk digunakan lebih lanjut di dalam negosiasi lanjutan atau sebagai dasar untuk melakukan studi kelayakan. Sebagai studi kelayakan bahwa setelah pihakpihak memperoleh Memorandum of Understanding sebagai pegangan atau pedoman awal, baru dilanjutkan dengan tahapan studi kelayakan

${ }^{31}$ Hikmahanto Juwana, Hukum Ekonomi dan Hukum Internasional, Jakarta: Lentera Hati, 2002, h.123.

32 Erman Rajagukguk dalam Salim H.S., H. Abdullah, dkk, Perancangan Kontrak dan Memorandum of

Understanding $(\mathrm{MoU}), \quad$ cetakan kelima, Jakarta: Penerbit Sinar Grafika, 2011, h. .46 (feasibility study, due diligent) untuk melihat tingkat kelayakan dan prospek transaksi bisnis tersebut dari berbagai sudut pandang yang diperlukan misalnya ekonomi, keuangan, pemasaran, teknik, lingkungan, sosial budaya dan hukum.

Memorandum of understanding itu sendiri dibuat dengan tujuan : 33

1. Untuk menghindari kesulitan pembatalan suatu agreement nantinya, dalam arti belum bisa dipastikan apakah kerja sama tersebut akan ditindaklanjuti, sehingga dibuatlah memorandum of understanding yang mudah dibatalkan.

2. Penandatanganan perjanjian masih lama karena masih dilakukan negosiasi yang alot. Karena itu, daripada tidak ada ikatan apa-apa sebelum ditandatangani perjanjian tersebut, dibuatlah memorandum of understanding yang akan berlaku sementara waktu.

3. Adanya keraguan para pihak dan masih perlu waktu untuk pikir-pikir dalam hal penandatanganan suatu perjanjian, sehingga untuk sementara waktu dibuatlah suatu memorandum of understanding.

Berdasarkan tujuan memorandum of understanding tersebut, dapat dilihat

33 Munir Fuady, dalam Salim H.S., H.Abdullah, dkk, Perancangan Kontrak dan Memorandum of Understanding(MoU), cetakan kelima,Jakarta: Penerbit Sinar Grafika, 2011; h. 2 
walaupun memorandum of understanding itu mudah dibatalkan dan belum mempunyai kekuatan mengikat secara hukum, namun dalam prakteknya memorandum of understanding tetap sering digunakan dalam membuat perjanjian di berbagai bidang kehidupan. Dikarenakan memorandum of understanding menunjukkan niat bahwa para pihak akan melanjutkan klausulklausul yang telah disepakati bersama dalam memorandum of understanding ke dalam suatu perjanjian.

\section{Memorandum of Understanding} (MoU) sebenarnya tidak dikenal dalam hukum konvensional di Indonesia, terutama dalam hukum kontrak di Indonesia. Di dalam peraturan perundang-undangan Indonesia, tidak ada ketentuan yang secara khusus mengatur tentang Memorandum of Understanding (MoU). ${ }^{34}$

Apabila telah terjadi persesuaian pernyataan kehendak dan telah ditandatanganinya kerja sama tersebut, maka memorandum of understanding telah mempunyai kekuatan untuk dapat dilaksanakan. Artinya bahwa memorandum of understanding tersebut mempunyai kekuatan yang mengikat ; akan tetapi dalam praktiknya, apabila salah satu pihak tidak melaksanakan memorandum of understanding itu, maka salah satu pihak tidak akan pernah mempersoalkan hal tersebut atau menggugat ke pengadilan. Namun

34 Fajar Sandy Wijaya, dkk, Kajian Yuridis Kekuatan Hukum Memorandum of Understanding (MoU) Indonesia- Singapura Tentang Kerjasama Kawasan Ekonomi Khusus, Jember: Universitas Jember, 2013, h. 2. demikian, para ahli hukum tidak dapat memberikan jawaban yang pasti tentang kekuatan mengikat dari memorandum of understanding tersebut.

Ketentuan yang mengatur tentang kesepakatan telah dituangkan dalam Pasal 1320 KUHPer. Pasal 1320 KUHPer ini mengatur tentang syaratsyarat sahnya perjanjian. Salah satu syarat sahnya perjanjian itu adalah adanya konsensus para pihak. Disamping itu, yang dapat dijadikan dasar hukum pembuatan Memorandum of Understanding adalah Pasal 1338 KUHPer berbunyi semua perjanjian yang dibuat secara sah berlaku sebagai undang-undang bagi mereka yang membuatnya.

Memorandum of Understanding dalam hal ini dapat disebut sebagai suatu perjanjian dengan segala macam konsekuensinya. Tetapi apabila dalam Memorandum of Understanding tersebut hanya mengenai suatu hal belum final dan masih membutuhkan perjanjian lain sebagai pendukungnya dan dalam Memorandum of Understanding tersebut tidak terdapat sanksi yang jelas terhadap pihak yang mengingkarinya, maka Memorandum of Understanding tersebut hanya berkedudukan dalam hal kesepakatan mengenai suatu proyek-proyek besar. Dan hal ini tentunya tidak mempunyai efek apapun terhadap kekuatan hukum suatu Memorandum of Understanding.

Negara Indonesia menganut sistem hukum dari civil law, di mana setiap anggota masyarakat akan mengacu terhadap ketentuan undang- 
undang yang lebih tinggi, maka kedudukan MoU (Memorandum of Understanding) harus mendapat perhatian karena tidak adanya pengaturan secara eksplisit di dalam pasal 1320 KUH Perdata. Secara sederhana konsep dari Memorandum of Understanding (MoU) adalah suatu nota kesepakatan yang dilakukan oleh para pihak yang ingin melakukan perjanjian. Akan tetapi, bila Memorandum of Understanding (Mou) tersebut juga mengacu kepada Pasal $1320 \mathrm{KUH}$ Perdata, maka ia memiliki kekuatan hukum yang sama dengan kekuatan hukum berdasarkan perjanjian yang terdapat di dalam sistem hukum Negara Indonesia, yakni sistem hukum Civil Law.

Mengenai kedudukan memorandum of understanding, para ahli belum mempunyai kesepahaman. Sebagian ahli hukum memandang memorandum of understanding bukan sebagai perjanjian karena isinya belum mencerminkan hakikat perjanjian, melainkan baru merupakan tindakan pendahuluan yang masih akan ditindaklanjuti dengan perjanjian yang sesungguhnya. Jadi dalam hal ini memorandum of understanding bukan merupakan perjanjian karena perjanjiannya sendiri belum terbentuk. Sementara sebagian ahli hukum yang lain berpendapat bahwa memorandum of understanding merupakan perjanjian karena elemen-elemennya dapat dianggap memenuhi persyaratan dan memiliki elemen perjanjian. Dalam memorandum of understanding ada kesepakatan diantara para pihak mengenai hal-hal pokok sehingga melahirkan perjanjian serta menimbulkan kekuatan mengikat.

Memorandum of understanding ini akan menjadi sah jika memenuhi syarat sahnya suatu perjanjian sebagimana tercantum dalam Pasal 1320 Kitab Undang-Undang Hukum Perdata. Karena adanya bermacam-macam pendapat mengenai kedudukan dari memorandum of understanding, maka dikenal dua macam pendapat sebagai berikut :35

a. Gentlemen Agreement. Pendapat ini mengajarkan bahwa memorandum of understanding hanyalah merupakan suatu gentlement agreement saja. Maksudnya kekuatan mengikatnya suatu memorandum of understanding tidak sama dengan perjanjian biasa, sungguh pun memorandum of understanding dibuat dalam bentuk yang paling kuat seperti dengan akta notaris sekalipun (tetapi dalam praktek jarang memorandum of understanding dibuat secara notarial). Bahkan menurut pendapat golongan ini menyatakan bahwa memorandum of understanding mengikat sebatas pada pengakuan moral belaka, dalam arti tidak punya daya ikat secara hukum.

b. Agreement is Agreement. Ada juga pihak yang berpendapat bahwa

35 Munir Fuady, Hukum Bisnis Dalam Teori dan Praktek, Buku Keempat, Bandung: PT. Citra Aditya Bakti, 2002, h. 92 
sekali suatu perjanjian dibuat, apapun bentuknya. Lisan atau tertulis, pendek atau panjang, lengkap/ detil ataupun hanya diatur pokok-pokoknya saja, tetap saja merupakan suatu perjanjian, dan karenanya mempunyai kekuatan hukum mengikat layaknya suatu perjanjian, sehingga seluruh ketentuan pasal-pasal tentang hukum perjanjian telah bisa diterapkan kepadanya. Dan menurut pendapat ini untuk mencari alas yuridis yang tepat bagi penggunaan memorandum of understanding adalah terdapat dalam pasal 1338 ayat $1 \mathrm{KUH}$ Perdata yang artinya apapun yang dibuat sesuai kesepakatan kedua belah pihak, merupakan hukum yang berlaku baginya sehingga mengikat kedua belah pihak tersebut. Selain itu menurut asas kebebasan berkontrak dan asas konsensual maka hal apa saja asalkan halal menurut hukum dan telah secara bebas disepakati maka berlaku suatu perjanjian atau jika diterapkan secara tertulis maka hal tersebut bisa dikatakan sebagai kontrak.

Pijakan lain dari pendapat diatas adalah dengan menggunakan suatu teori yang disebut teori promissory estopel. Teori promissory estoppel atau disebut juga dengan detrimental reliance mangajarkan bahwa dianggap ada kesesuaian kehendak di antara para pihak jika pihak lawan telah melakukan sesuatu sebagai akibat dari tindakantindakan pihak lainnya yang dianggap merupakan tawaran untuk ikatan suatu kontrak. ${ }^{36}$

Doktrin lainnya adalah Teori kontrak quasi (quasi contract atau implied in law). Teori ini mengajarkan bahwa dalam hal-hal tertentu, apabila dipenuhi syarat-syarat tertentu, maka hukum dapat menganggap adanya kontrak di antara para pihak dengan berbagai konsekuensinya, sungguhpun dalam kenyataannya kontrak tersebut tidak pernah ada. ${ }^{37}$

Suatu perjanjian jika yang diatur hanya hal-hal pokok saja, maka mengikatnya hanya pun hanya terhadap hal-hal pokok tersebut. Sama halnya jika suatu perjanjian hanya berlaku untuk suatu jangka waktu tertentu, maka mengikatnya pun hanya untuk jangka waktu tertentu tersebut. Sungguh pun para pihak tidak dapat dipaksakan untuk membuat perjanjian yang lebih rinci sebagai tindak lanjut dari memorandum of understanding, paling tidak, selama jangka waktu perjanjian itu masih berlangsung, para pihak tidak boleh membuat perjanjian yang sama dengan pihak lain. Ini tentu jika dengan tegas disebutkan untuk itu dalam memorandum of understanding tersebut.

Berdasarkan uraian tersebut diatas, maka dapat disimpulkan bahwa untuk mengetahui kedudukan dari memorandum of understanding diperlukan suatu pengamatan yang jeli terhadap substansi yang terdapat dalam

$$
\begin{aligned}
& { }^{36} \mathrm{Ibid} \\
& { }^{37} \mathrm{Ibid}
\end{aligned}
$$


memorandum of understanding tersebut, apakah materinya mengandung unsur kerugian non moral atau kerugian secara finansial apabila tidak dilakukannya pemenuhan prestasi dan apakah dalam memorandum of understanding mengandung sanksi atau tidak. Apabila menimbulkan suatu kerugian non moral yaitu material dan mengandung suatu sanksi yang jelas bagi para pihak yang mengingkarinya, maka memorandum of understanding tersebut sudah berkedudukan sebagai kontrak dan dianggap sudah setingkat dengan perjanjian berdasarkan pasal 1338 KUH Perdata mengenai kebebasan berkontrak. Walaupun memorandum of understanding tidak pernah disebutkan dengan tegas bahwa itu merupakan suatu kontrak, akan tetapi kenyataannya kesepakatan semacam memorandum of understanding ini memang ada seperti yang ditegaskan dalam teori kontrak de facto (implied in-fact), yakni sudah disebut sebagai kontrak, walaupun tidak pernah disebutkan dengan tegas tetapi ada kenyataan, pada prinsipnya dapat diterima sebagai kontrak yang sempurna. ${ }^{38}$ memorandum of understanding dalam hal ini apabila dikaitkan dengan teori ini maka dapat disebut sebagai suatu kontrak dengan segala macam konsekuensinya.

Secara teori kedudukan Memorandum of understanding bukanlah merupakan suatu kontrak karena memang masih merupakan kegiatan pra kontrak. Karena itu, di dalamnya sengaja tidak dimasukkannya unsur "intention to create legal relation" oleh pihak yang melakukan tersebut. Pada dasarnya Memorandum of Understanding yang dibuat diantara para pihak hanya berisi hal-hal pokok saja, seperti kesepakatan mengenai apa yang menjadi objek perjanjian dan kesepakatan mengenai waktu pengerjaan. Didalam Memorandum of Understanding, biasanya yang menjadi hak-hak dan kewajiban dari para pihak tidak dicantumkan, artinya pelaksanaan dari Memorandum of Understanding tersebut hanya bermodalkan kepercayaan dari masing-masing pihak.

\section{Akibat Hukum Apabila Terjadi Wanprestasi Terhadap Klausula Memorandum of Understanding}

Wanprestasi merupakan situasi dimana salah satu pihak dalam sebuah perjanjian tidak melaksanakan kewajibannya sesuai dengan yang telah disepakati dalam perjanjian tersebut. Menurut Amirizal, tindakan wanprestasi membawa konsekuensi terhadap timbulnya hak pihak yang dirugikan untuk menuntut pihak yang melakukan wanprestasi untuk melakukan pemenuhan prestasi, sehingga oleh hukum diharapkan agar tidak ada satu pun pihak yang dirugikan karena prestasi tersebut. ${ }^{39}$

Prestasi diartikan sebagai suatu pelaksanaan hal-hal yang tertulis dalam suatu perjanjian atau hal-hal yang telah disepakati bersama, oleh pihak yang telah mengikatkan diri untuk itu.

39 Amirizal, Hukum Bisnis, Risalah Teori dan Praktik, Jakarta: Djambatan, 1999, h.36 
Sedangkan pelaksanaan prestasi disesuaikan dengan syarat-syarat yang telah disebutkan dalam perjanjian yang bersangkutan. Namun demikian pada kenyataannya sering dijumpai bahwa pelaksanaan dari suatu perjanjian tidak dapat berjalan dengan baik karena salah satu pihak wanprestasi.

$$
\text { Pasal } 1234 \text { KUHPerdata }
$$

menentukan bahwa prestasi dapat berupa:

1. memberikan sesuatu;

2. berbuat sesuatu;

3. tidak berbuat sesuatu.

Wanprestasi berasal dari bahasa Belanda wanprestatie artinya tidak memenuhi kewajiban yang telah ditetapkan dalam perikatan, baik yang timbul perjanjian maupun perikatan yang timbul karena undang-undang. Suatu perjanjian lahir pada detik tercapainya kesepakatan atau persetujuan kedua belah pihak mengenai apa yang menjadi obyek perjanjian atau dengan kata lain wanprestasi berarti prestasi buruk. ${ }^{40}$ Apabila si berutang tidak melakukan apa yang dijanjikannya, maka dikatakan telah melakukan wanprestasi. Ia alpa atau lalai atau ingkar janji. Wanprestasi seorang debitur dapat berupa empat macam: ${ }^{41}$

a. Tidak melakukan apa yang disanggupi dilakukannya;

40 Ridwan Syahrani, Seluk Beluk dan Azaz-Azaz. Hukum Perdata, Bandung: Alumni, 1989, h. 280.

41 Subekti, Hukum Perjanjian, Jakarta: Intermasa, 2002, h. 45 b. Melaksanakan apa yang dijanjikannya, tetapi tidak sebagaimana dijanjikan;

c. Melakukan apa yang dijanjikan tetapi terlambat;

d. Melakukan sesuatu yang menurut perjanjian tidak boleh dilakukannya.

R. Subekti menambahkan bahwa sesuatu yang menurut perjanjian tidak boleh dilakukan. Melakukan prestasi tetapi terlambat atau tidak tepat waktu. ${ }^{42}$ Tindakan wanprestasi membawa konsekuensi terhadap timbulnya hak pihak yang dirugikan untuk menuntut pihak yang melakukan wanprestasi untuk melakukan pemenuhan prestasi, sehingga oleh hukum diharapkan agar tidak ada satu pun pihak yang dirugikan karena prestasi tersebut. ${ }^{43}$

Ada berbagai model bagi para pihak yang tidak memenuhi prestasinya. Model-model wanprestasi tersebut adalah sebagai berikut:

1) Wanprestasi berupa tidak memenuhi prestasi;

2) Wanprestasi berupa terlambat memenuhi prestasi;

3) Wanprestasi berupa tidak sempurna memenuhi prestasi. ${ }^{44}$ Wanprestasi yang terjadi dalam substansi dari Memorandum of Understanding dapat dikategorikan menjadi dua bagian yaitu:

42 Abdulkadir Muhammad, Hukum Perikatan, PT Citra Aditya Bakti, Bandung, 1990, h 23.

43 Amirizal. Op. cit, h 36

${ }^{44}$ Munir Fuady. Op. Cit. hlm 89 
a) Wanprestasi terhadap substansi Memorandum of Understanding yang tidak berkedudukan sebagai kontrak.

b) Pengingkaran substansi Memorandum of Understanding yang berkedudukan sebagai kontrak (wanprestasi).

Untuk Memorandum of Understanding yang sifatnya bukan merupakan suatu kontrak maka tidak ada sanksi apapun bagi pihak yang mengingkarinya kecuali sanksi moral. Upaya penyelesaian untuk masalah ini lebih pada musyawarah untuk mencari suatu jalan keluarnya. Adanya sanksi moral dalam hal ini dimisalkan bahwa pihak yang wanprestasi.

Kemudian bagaimana dengan kedudukan dari Memorandum of Understanding yang tidak mempunyai suatu kekuatan hukum yang memaksa (sanksi) sehingga bisa mempunyai sanksi. Hal itu tentunya tidak terlepas dari teori ratifikasi. Dimana yang dimaksud dengan ratifikasi disini adalah suatu tindakan pengakuan yang menguatkan tindakan yang telah dilakukan sebelumnya, dalam hal ini akan menguatkan perjanjian yang telah dilakukan sebelumnya. ${ }^{45}$

Jadi dalam hal ini Memorandum of Understanding yang telah dibuat sebelumnya diratifikasi menjadi sebuah kontrak baru dengan substansi lebih tegas menyangkut hak dan kewajiban masing-masing pihak disertai dengan sanksi yang tegas pula jika terdapat suatu pelanggaran.

45 Amirizal. Op. Cit. hlm 63

\section{Penutup}

Adapun kesimpulan yang peneliti dapatkan dari telaah ini adalah:

1. Di dalam berbagai peraturan perundang-undangan tidak ditemukan ketentuan yang khusus mengatur tentang Memorandum of Understanding, namun apabila memperhatikan substansi Memorandum of Understanding, maka jelaslah bahwa di dalamnya berisi kesepakatan para pihak tentang halhal yang bersifat umum. Memorandum of Understanding atau disingkat MoU sebagaimana telah diuraikan merupakan pencatatan atau pendokumentasian hasil negosiasi awal dalam bentuk tertulis. penggunaan istilah Memorandum of Understanding harus dibedakan dari segi teoritis dan praktis. Secara teoritis, dokumen Memorandum of Understanding tidak mengikat secara hukum, agar dapat mengikat secara hukum harus ditindaklanjuti dengan membuat suatu perjanjian. Sedangkan apabila mengacu pada KUHPer yang menyamakan Memorandum of Understanding dengan perjanjian, walaupun Pasal 1338 KUHPer mengatakan bahwa setiap perjanjian yang dibuat secara sah mengikat sebagai undang-undang bagi para pihak yang membuatnya (Pacta Sunt Servanda), akan tetapi apabila unsur-unsur sahnya perjanjian dalam Pasal 1320 KUHPer tidak terpenuhi, maka Memorandum of Understanding tersebut 
batal demi hukum, dan tidak mempunyai kekuatan hukum. Kedudukan Memorandum of understanding bukanlah merupakan suatu kontrak karena memang masih merupakan kegiatan pra kontrak. Karena itu, di dalamnya sengaja tidak dimasukkannya unsur "intention to create legal relation" oleh pihak yang melakukan tersebut. Pada dasarnya Memorandum of Understanding yang dibuat diantara para pihak hanya berisi hal-hal pokok saja, seperti kesepakatan mengenai apa yang menjadi objek perjanjian dan kesepakatan mengenai waktu pengerjaan. Didalam Memorandum of Understanding, biasanya yang menjadi hak-hak dan kewajiban dari para pihak tidak dicantumkan, artinya pelaksanaan dari Memorandum Of Understanding tersebut hanya bermodalkan kepercayaan dari masing-masing pihak. $\backslash$

2. Wanprestasi merupakan situasi dimana salah satu pihak dalam sebuah perjanjian tidak melaksanakan kewajibannya sesuai dengan yang telah disepakati dalam perjanjian tersebut. Tindakan wanprestasi membawa konsekuensi terhadap timbulnya hak pihak yang dirugikan untuk menuntut pihak yang melakukan wanprestasi untuk melakukan pemenuhan prestasi, sehingga oleh hukum diharapkan agar tidak ada satu pun pihak yang dirugikan karena prestasi tersebut. Memorandum of Understanding yang sifatnya bukan merupakan suatu kontrak maka tidak ada sanksi apapun bagi pihak yang wanprestasi kecuali sanksi moral. Upaya penyelesaian untuk masalah ini lebih pada musyawarah untuk mencari suatu jalan keluarnya. Adanya sanksi moral dalam hal ini dimisalkan bahwa pihak yang wanprestasi.

\section{DAFTAR PUSTAKA}

\section{Buku-buku}

Subekti, Pokok-pokok Hukum Perdata, Jakarta: Intermasa, 1995

Salim H. Perancangan Kontrak dan Memorandum of Understanding (MoU). Sinar Grafika. Mataram. 2007

Perkembangan Hukum Kontrak, Inominat di Indonesia, cet 3. Sinar Grafika. Jakarta. 2005

Yohanes Sogar Simamora.Hukum Perjanjian Prinsip Hukum KontrakPengadaan Barang dan Jasa oleh Pemerintah). LaksBangPressindo:. Yogya karta. 2009,

Munir Fuady, Hukum Kontrak, Dari Sudut Pandang Hukum Bisnis, Bandung: PT. Citra Aditya Bakti, 1999, Huala Adolf, Dasar-dasar Hukum Kontrak Internasional, edisi Revisi, Bandung: Refika Aditama, 2008.

Agus Yudha Hernoko. Hukum Perjanjian, Asas Proporsionalitas dalamKontrak Komersial, Yogyakarta: 
Jurnal Syariah: Jurnal Ilmu Hukum dan Pemikiran

LaksBang Mediatama, 2008.

Fajar Sandy Wijaya, dkk, Kajian Yuridis

Kekuatan

Hukum

Memorandum of Understanding

(MoU) Indonesia- Singapura

Tentang Kerjasama Kawasan

Ekonomi Khusus, Jember:

Universitas Jember, 2013.

Niniek Suparni, Kitab Undang-Undang

Hukum Perdata

(KUHPerdata), Jakarta:

Rineka Cipta, 2013

Abdul R.Salimin, Hukum Bisnis Untuk

Perusahaan (Teori Dan Contoh

Kasus), Jakarta: Kencana, $2010,{ }^{1}$

Wirjono Prodjodikoro, 1981, Hukum

Perdata Tentang Persetujuan-

persetujuan Tertentu,

Bandung: Sumur,

R. Setiawan, 1987, Pokok-Pokok Hukum

Perikatan, Bandung:

Binacipta 1987.

H. Riduan syahrani, 2006, Seluk Beluk dan Asas-Asas Hukum Perdata, Bandung: Alumni

Ricardo Simanjuntak,. 2011.Hukum Kontrak, Teknik Perancangan Kontrak Bisnis, Edisi Revisi, Jakarta: Kontan Publishing,

Munir Fuady, Hukum Bisnis dalam Teori dan Praktik, Bandung: Citra Aditya Bhakti, 1997

Ikmahanto Juwana, 2002, Hukum Ekonomi dan Hukum Internasional, Jakarta: Lentera Hati

Fajar Sandy Wijaya, dkk, Kajian Yuridis Kekuatan

Hukum
Memorandum of Understanding (MoU) Indonesia- Singapura Tentang Kerjasama Kawasan Ekonomi Khusus, Jember: Universitas Jember, 2013

Munir Fuady, Hukum Bisnis Dalam Teori dan Praktek, Bandung: Buku Keempat, PT. Citra Aditya Bakti, 2002

\section{Peraturan Perundang-undangan}

Undang-Undang Dasar NRI Tahun 1945

Kitab Undang-Undang Hukum Perdata (Bergelijk Wetbook) 